\title{
高温高圧水用固体電解質型照合電極の開発*
}

\author{
藤木泰史 ${ }^{* *}$, 相馬才晃 ${ }^{* * *}$, 赤尾 昇 ${ }^{* * *}$, 原 信義 ${ }^{* * *}$, 杉本克久*** \\ ** 東北大学大学院院生 \\ 東北大学大学院工学研究科金属工学専攻
}

\section{Development of Solid Electrolyte Reference Electrode for High Temperature Water System*}

\author{
Yasufumi Fujiki**, Saikou Souma**, Noboru Akao***, Nobuyoshi Hara*** \\ and Katsuhisa Sugimoto*** \\ ** Graduate Student of Tohoku University \\ *** Department of Metallurgy, Graduate School of Engineering, Tohoku University
}

\begin{abstract}
A newly designed solid electrolyte internal reference electrode has been developed for electrochemical measurement in high temperature water systems. This reference electrode is composed of an yttria stabilized zirconia (YSZ) disk electrode with a sputter-deposited $\mathrm{Ni} \cdot \mathrm{NiO}$ composite film on the backside, an asbestos plug soaked with a neutral phosphate buffer solution as an internal solution and an oxidized zircaloy- 4 body. The thermodynamic response of the YSZ reference electrode has been confirmed in phosphate buffer solutions ( $\mathrm{pH}$ 4.4 9.3) with an $\mathrm{Ag} / \mathrm{AgCl}\left(0.1 \mathrm{kmol} \cdot \mathrm{m}^{-3} \mathrm{KCl}\right)$ internal reference electrode at temperatures up to $523 \mathrm{~K}$. It was found that the potential of the YSZ reference electrode has the following linear relationship with temperature:

$E_{\mathrm{YSZ} / \mathrm{Ni} \cdot \mathrm{NiO}}=2395-5.37 \mathrm{~T} / \mathrm{mV}$ vs. SHE

Using the YSZ reference electrode, the measurement of anodic polarization curves of Type 304 stainless steel in a $0.5 \mathrm{kmol} \cdot \mathrm{m}^{-3} \mathrm{Na}_{2} \mathrm{SO}_{4}$ solution at temperatures up to $563 \mathrm{~K}$ has been performed. Anodic polarization curves measured with the YSZ reference electrode coincided with those with the $\mathrm{Ag} / \mathrm{AgCl}$ internal reference electrode in the temperature range from $473 \mathrm{~K}$ to $563 \mathrm{~K}$.
\end{abstract}

Key words : yttria stabilized zirconia, high temperature water, internal reference electrode, electrochemical potential, oxidized zircaloy, anodic polarization curve

\section{1. 緒言}

材料の腐食特性は水溶液の $\mathrm{pH}$, 溶存酸素濃度, 電気 伝導度および不純物成分などのいわゆる水化学因子に よって大きな影響を受け，材料はこのような水化学因子 の条件に応じた腐食電位を示す。したがって，腐食電位 をモニタリングしながら水管理を行えば，危険な腐食を 防止することが可能である。例えば，沸騰水型原子炉 （BWR）の炻水環境下では，鋭敏化 304 ステンレス鋼 はー0.230 V vs. SHE よりも貴な電位になると粒界応 力腐食割れ (IGSCC) を起こすことが知られているの

* 材料と環境' 97 (東京, 1997 年) で発表

**,*** 厂980-8579 仙台市青葉区荒巻字青葉（Aza-Aoba, Aramaki, Aoba-ku, Sendai, 980-8579 Japan)
で1)，この電位を超えないように水化学因子をコント ロールすれば，IGSCC の発生を防止することができ る。

高温高圧水環境下での腐食電位のモニタリングには高 温高圧水用の照合電極が不可欠であり, 各種の高温高圧 水用の照合電極が開発されている2)。これらの中で現在 使用されているのは銀/塩化銀電極を用いる内部照合電 極と外部照合電極であり, 前者にはテフロン膜で圧力緩 衝を行う高林ら ${ }^{3)}$ の電極や杉本ら ${ }^{4)}$ の電極があり, 後者 にはテフロン管で圧力平衡をとる Macdonald ら 5),6)の 電極や可動式ピストンによって圧力平衡をとる滳の電 極7) がある。いずれにしても現在実用されているのは, 銀/塩化銀型の高温高圧水用照合電極だけである。

最近になり BWR 炉心環境での腐食計測に関心が向 
けられるようになってから, 炣心環境での銀/告化銀電 極の使用においては, 次のような問題点が指摘されるよ うになった。一つは電極素子の $\mathrm{Ag} / \mathrm{AgCl}$ や電極容器 のテフロンが炉内での照射により变質する恐れがあるこ $と^{8), 9)}$ であり, 屯う一つは電極内部液の $\mathrm{KCl}$ の漏洩に よりプラント構成材料が孔食を起こす危険性があること である。このような問題点を解決するには, $\mathrm{Ag} / \mathrm{AgCl}$ 電㥛を使わないこと，テフロンをできるだけ使わないこ と，および内部液に KCI を使わないことが必要になる。 このような条件をすべて満たすことは現時点では難しい が, 本研究では, $423 \sim 573 \mathrm{~K}\left(150 \sim 300^{\circ} \mathrm{C}\right)$ の高温水 中でかっ照射下でも使用可能な照合電極を開発すること を目的として，(1)電極素子としてジルコニア固体電解質 円板，(2)酸素基準電極として上記ジルコニア円板にス パッ夕蒸着した $\mathrm{Ni} \cdot \mathrm{NiO}$ 複合酸化物薄膜, (3)電極容器 として高温酸化処理をしたジルカロイー4 合金, (4)電極 内部液として $\mathrm{pH} 6.68$ (298K) の $\mathrm{NaH}_{2} \mathrm{PO}_{4}+\mathrm{Na}_{2} \mathrm{H}$ $\mathrm{PO}_{4}$ 緩衝液を使用した基準電極一体型固体電解質内 部照合電極の試作を行った。次に，この照合電極を従来 の $\mathrm{Ag} / \mathrm{AgCl}\left(0.1 \mathrm{kmol} \cdot \mathrm{m}^{-3} \mathrm{KCl}\right)$ 内部照合電極と組 み合わせて, 高温水中での起電力の温度变化及び $\mathrm{pH}$ 依 存性についての熱力学的検証を行った。そして最後に, 試作した照合電極を用いて SUS 304 ステンレス鋼の分 極曲線測定を行い，従来同条件で測定されているこの鋼 の分極曲線と比較し, 試作照合電極が分極曲線測定に正 しく用いることができるかどうか確認した。

\section{2. 照合電極の動作原理}

酸素イオン伝導性のイットリア安定化ジルコニア （YSZ）は，これまで工業的には高温用のガスセンサー として使用されてきた。しかしながら，Niedrach ${ }^{10), 11)}$ により基準電極に $\mathrm{Cu} / \mathrm{Cu}_{2} \mathrm{O}$ を用いた $\mathrm{YSZ} \mathrm{pH}$ セン サーが開発されてから, 高温高圧水中での $\mathrm{pH}$ 測定の研 究にも数多く利用されるようになった ${ }^{12) ~ 16) 。 ~}$

著者ら ${ }^{16)}$ も, $\mathrm{Ni} \cdot \mathrm{NiO}$ 複合酸化物薄膜（ナノメータサ イズの $\mathrm{Ni}$ 粒子と $\mathrm{NiO}$ 粒子の混合物薄膜) を基準電極 に用いた YSZ 円板 $\mathrm{pH}$ センサーを試作し，423〜 523K の温度範囲で $\mathrm{pH}$ センサーの起電力之試験溶液の $\mathrm{pH}$ と の間に直線関係が得られることを明らかにした ${ }^{16)}$ 。本研 究のジルコニア固体電解質照合電極（YSZ 炤合電極と 略する）は，この YSZ 円板 $\mathrm{pH}$ センサーを基に作製し た。

$\mathrm{Ni} \cdot \mathrm{NiO}$ を基準電極に用いる YSZ 照合電極の電池構 成は次の通りである。

$\mathrm{Ni}, \mathrm{NiO}|\mathrm{YSZ}| \mathrm{H}_{2} \mathrm{O}, \mathrm{H}^{+}$(内部液) |試験液

(I) (II)

内部液は $\mathrm{pH}$ 6.68(298 K)のリン酸塭緩衝溶液である。
$\mathrm{YSZ}$ と $\mathrm{Ni} ・ \mathrm{NiO}$ との界面（I）および YSZ と内部液と の界面（II）における反応は，それぞれ次式で表され る。

$$
\begin{aligned}
& \mathrm{V}_{0} \ddot{\circ}+\mathrm{NiO}+2 \mathrm{e}^{-}=\mathrm{O}_{\mathrm{o}}+\mathrm{Ni} \quad(\text { 界面 (I)) } \\
& \mathrm{V}_{0} \ddot{\circ}+\mathrm{H}_{2} \mathrm{O}=\mathrm{O}_{\mathrm{o}}+2 \mathrm{H}^{+} \quad \text { (界面 (II)) }
\end{aligned}
$$

ここで $V_{0}$ は $\mathrm{YSZ}$ 表面の酸素イオン空孔，O。は陰イオ ン格子点の酸素イオンを表している。酸素イオン空孔が YSZ 円板内部に均一に分布していると仮定すると, 電 池(1)の起電力は次式で与えられる。

$$
\begin{aligned}
E_{\mathrm{Ni} \cdot \mathrm{NiO}}= & E^{0}{ }_{\mathrm{Ni}} \cdot \mathrm{NiO}-(R T / 2 F) \ln \left(a_{\mathrm{H}_{2} \mathrm{O}}\right) \\
& -(2.303 R \mathrm{pH} / F) T
\end{aligned}
$$

ここで $a_{\mathrm{H}_{2} \mathrm{O}}$ は $\mathrm{H}_{2} \mathrm{O}$ の活量, $E^{0}{ }_{\mathrm{Ni}}$-NiO は次式の反応の標 準電極電位である。

$$
\mathrm{NiO}+2 \mathrm{H}^{+}+2 \mathrm{e}^{-}=\mathrm{Ni}+\mathrm{H}_{2} \mathrm{O}
$$

内部液の水素イオン濃度が一定であるような $\mathrm{pH}$ セン サーを構成すれば式(4)の右辺第 3 項は一定となるの で, $\mathrm{H}_{2} \mathrm{O}$ の活量が一定であれば照合電極の電位は Nernst 応答することになる。

\section{3. 実験方法}

\section{1 照合電極の構造}

Fig. 1 に本研究で試作した基準電極一体型ジルコニ ア固体電解質照合電極の概要を示す。

電極本体には, $873 \mathrm{~K}\left(600^{\circ} \mathrm{C}\right)$ で $7.2 \mathrm{ks}(2 \mathrm{~h})$ の酸

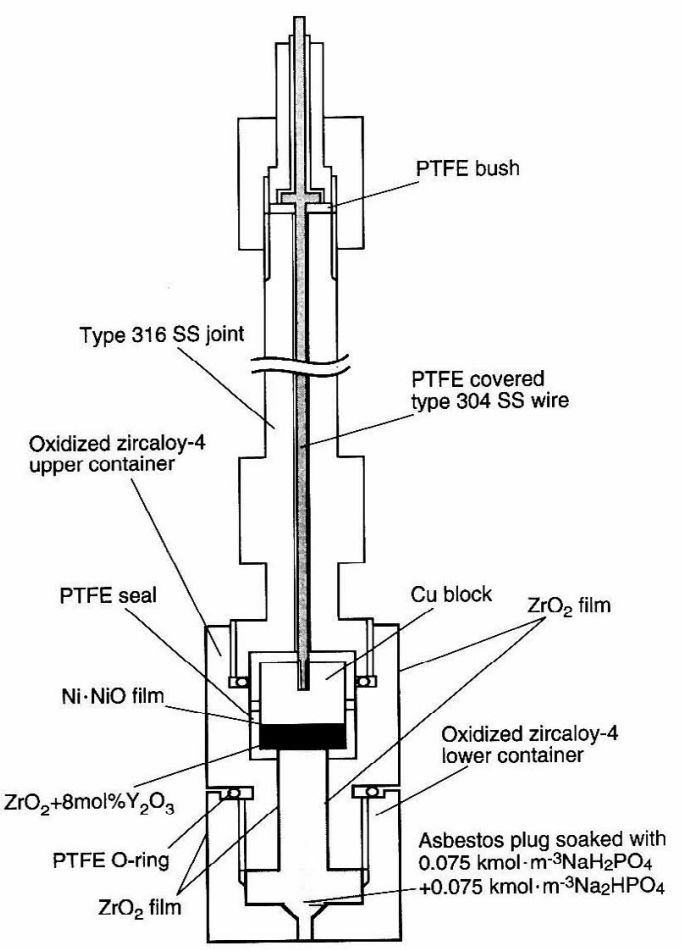

Fig.1 Schematic of the YSZ reference electrode. 
Table 1 Resistance of oxidized zircaloy- 4 .

\begin{tabular}{c|c}
\hline Oxidation condition & Resistance $/ \mathrm{M} \Omega \cdot \mathrm{m}^{2}$ \\
\hline $923 \mathrm{~K} \times 7.2 \mathrm{ks}$ & $1.22 \times 10^{-3}$ \\
\hline $873 \mathrm{~K} \times 3.6 \mathrm{ks}$ & $2.31 \times 10^{-5}$ \\
\hline $873 \mathrm{~K} \times 7.2 \mathrm{ks}$ & $5.71 \times 10^{-3}$ \\
\hline $873 \mathrm{~K} \times 10.8 \mathrm{ks}$ & $2.10 \times 10^{-4}$ \\
\hline $773 \mathrm{~K} \times 7.2 \mathrm{ks}$ & $5.31 \times 10^{-6}$ \\
\hline
\end{tabular}

化処理を行ったジルカロイ -4 合金（Sn：1.520, Ni : $0.227, \mathrm{Cr}: 0.117$, 残 $\mathrm{Zr}$, mass\%) 製の上部容器お よび下部容器が使用されている。ジルカロイ-4 合金製 容器の酸化処理は, Table 1 に示す 5 種類の条件で形成 した酸化皮膜の中で絶縁性試験で最も高い抵抗值が得ら れた条件 $(873 \mathrm{~K} \times 7.2 \mathrm{ks})$ で行った。この条件で得ら れた皮膜の厚さは $0.270 \mathrm{~mm}$ ，比抵抗は $2.11 \times 10^{7} \Omega$ ・ $\mathrm{m}\left(2.11 \times 10^{9} \Omega \cdot \mathrm{cm}\right)$ であった。電極素子には, 片面 に基準電極となる $\mathrm{Ni} \cdot \mathrm{NiO}$ 複合酸化物をイオンビームス パッタ蒸着した円板状の安定化ジルコニア(8 mol\% $\mathrm{Y}_{2} \mathrm{O}_{3}$ 今有, 直径 $15 \mathrm{~mm}$, 厚さ $3 \mathrm{~mm}$ ) を用い, $\mathrm{Ni}$ ・ $\mathrm{NiO}$ 薄膜が銅ブロックに接触するようにテフロンシー ルで固定した。 $\mathrm{Ni} ・ \mathrm{NiO}$ 薄膜の膜厚は約 $300 \mathrm{~nm}$ であり, $\mathrm{Ni}$ と $\mathrm{NiO}$ の成分モル比は 4:6である。ここで, $\mathrm{Ni}$ ・ $\mathrm{NiO}$ をイオンビームスパッ夕蒸着した理由は, 次の通 りである。すなわちこの電極の電位は $\mathrm{Ni} と \mathrm{NiO} の$ 平衡酸素分圧を基準として決定されるので，基準電極が 平衡酸素分圧を得るには被测定系の雺国気や大気に接す るのを避けねばならず，基準電極作製の際に電極/ジル コニア界面に大気が侵入するのを防止するた め, 欠宿密度が小さくかつ密着性の良い膜を 形成する必要があるためである。内部夜とし て $298 \mathrm{~K}$ で $\mathrm{pH} 6.68$ の $0.075 \mathrm{kmol} \cdot \mathrm{m}^{-3}$ $\mathrm{NaH}_{2} \mathrm{PO}_{4}+0.075 \mathrm{kmol} \cdot \mathrm{m}^{-3} \mathrm{Na}_{2} \mathrm{HPO}_{4}$ を 約 $0.9 \mathrm{~g}$ のアスベストに含浸させた状態で上 部容器の下部および下部容器の中空部分に詰 め, YSZ 電極の表面が溶液に接するように した。

YSZ 電極からの電気信号は，基準電極面 から $\mathrm{Cu}$ 製円柱ブロックを介し，ステンレス 鋼製のリード線を通してオートクレーブ外部 に引き出す構造になっている。YSZ 電極お よび電気的導通用の部品は, すバてテフロン 製の部品によって外側のステンレス鋼製部品 およびオートクレーブとは絶縁されている。 前述のようにテフロンは放射線照射下では少 化するので使用は避けたいが，適当な代替の 材料がないので必要最小限の使用にとどめ
た。高温酸化ジルカロイ - 4 合金製の上部容器と下部容 器の間, および上部容器とステンレス鋼製のジョイント との間には，外部溶液の侵入を防ぐためにテフロン製 ○ーリングが入れられている。なお，本研究は高温高压 下での実験であるため，テフロンシールおよびテフロン Oーリングは軟化・変形し，そのためシーリングが低下 するので，これらは試験のたびに交換した。

\section{2 熱力学的特性試験}

Fig. 2 に高温高圧起電力测定装置の概略を示す。 オートクレーブは SUS 316 鋼製で, 内容積 $1 \times 10^{-3} \mathrm{~m}^{3}$ の静水型である。オートクレーブの蓋には電気化学的測 定が行えるように試料極，照合電極および Pt 対極を取 り付けるための工夫がしてある。オートクレーブは SUS 316 鋼製であるため，このオートクレーブの内壁 が直接高温の酸性試験溶液にさらされるとオートクレー ブ自体の溶解が起こり, 試験溶液が污染される。そこで, 本研究では，できるだけ理想的な状態で測定を行うため に，耐食性が良くかつ熱伝導性の良い Ta 製のビーカー をオートクレープの内壁にはば密着する形で設置した。 さらに熱伝導を高めるために，オートクレーブとビー カーの間に精製水を入れてウォーターバスとした。ビー カーを支えるアルミナブロックの上およびビーカーの底 には，それぞれアノード防食用の Pt 線および Pt 板を いれた。また実験中に，オートクレーブ系内の溶液の沸 騰により気泡が生じ, 照合電極の液洛を遮断する恐れが あるので，昇温前に実験系内を精製 $\mathrm{N}_{2}$ ガスにより 1 MPaに加圧した。

Table 2 に测定に用いた 4 種類の $\mathrm{pH}$ 緩衝溶液とそれ

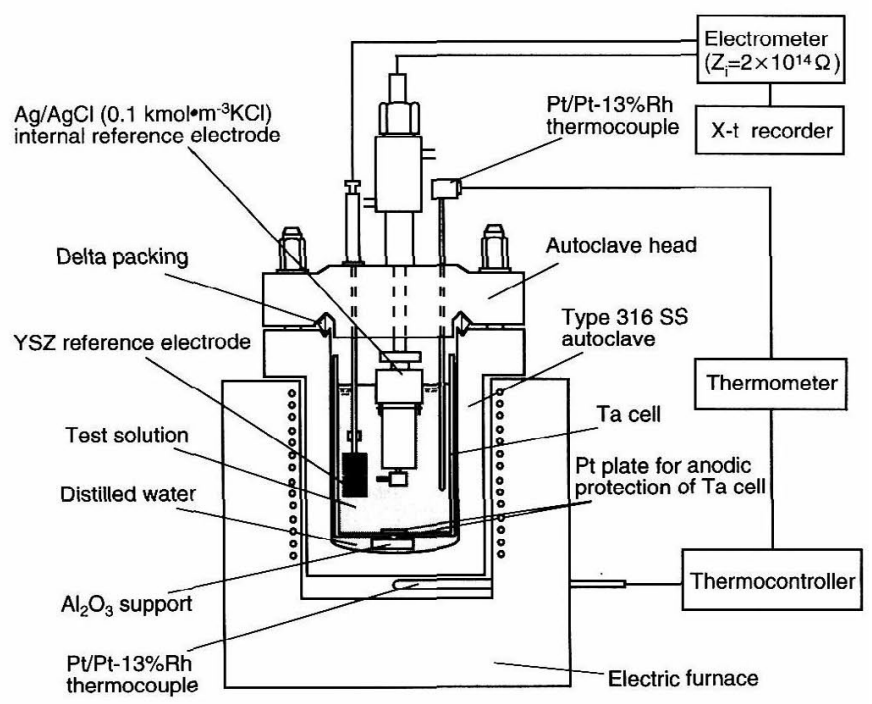

Fig.2 Measurement system for the YSZ solid electrolyte reference electrode. 
Table 2 Composition and $\mathrm{pH}$ of test solutions.

\begin{tabular}{c|c|c|c|c}
\hline \multirow{2}{*}{ Composition } & \multicolumn{4}{|c}{$\mathrm{pH}$} \\
\cline { 2 - 5 } & $298 \mathrm{~K}$ & $423 \mathrm{~K}$ & $473 \mathrm{~K}$ & $523 \mathrm{~K}$ \\
\hline $0.150 \mathrm{kmol} \cdot \mathrm{m}^{-3} \mathrm{NaH}_{2} \mathrm{PO}_{4}$ & 4.40 & 4.88 & 5.18 & 5.54 \\
\hline $\begin{array}{l}0.135 \mathrm{kmol} \cdot \mathrm{m}-3 \mathrm{NaH}_{2} \mathrm{PO}_{4} \\
+0.015 \mathrm{kmol} \cdot \mathrm{m}-3 \mathrm{Na}_{2} \mathrm{HPO}_{4}\end{array}$ & 5.81 & 6.05 & 6.30 & 6.63 \\
\hline $\begin{array}{l}0.075 \mathrm{kmol} \cdot \mathrm{m}-3 \mathrm{NaH}_{2} \mathrm{PO}_{4} \\
+0.075 \mathrm{kmol} \cdot \mathrm{m}-3 \mathrm{Na}_{2} \mathrm{HPO}_{4}\end{array}$ & 6.68 & 6.90 & 7.14 & 7.44 \\
\hline $0.150 \mathrm{kmol} \cdot \mathrm{m}-3 \mathrm{Na}_{2} \mathrm{HPO}_{4}$ & 9.25 & 8.67 & 8.60 & 8.65 \\
\hline
\end{tabular}

らの $298 \mathrm{~K} ， 423 \mathrm{~K}, 473 \mathrm{~K}$ および $523 \mathrm{~K}$ における $\mathrm{pH}$ 值を示す。ただし, Table 2 における值はすべて計算値 である。実験にはこれらの溶液を脱気しない状態で $5 \times$ $10^{-4} \mathrm{~m}^{3}(0.5 l)$ 使用した。オートクレーブを電気炉の 中に設置し, 溶液は室温から約 $1.79 \times 10^{-2} \mathrm{~K} / \mathrm{s}(64.4$ $\left.{ }^{\circ} \mathrm{C} / \mathrm{h}\right) \sim 1.89 \times 10^{-2} \mathrm{~K} / \mathrm{s}\left(68.2^{\circ} \mathrm{C} / \mathrm{h}\right)$ の昇温速度で試 験温度まで昇温した。設定温度は土 $1^{\circ} \mathrm{C}$ 精度で制御し

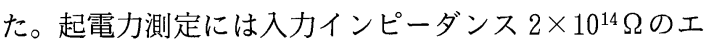
レクトロメータ（Keithley Model 617）を使用し, X-t レコーダ（渡辺測器製 SR6101-L）で電位を記録した。 YSZ 固体電解質照合電極の電位を測定するための照合 電極としては, 著者らの研究室で開発した $\mathrm{Ag} / \mathrm{AgCl}$ $\left(0.1 \mathrm{kmol} \cdot \mathrm{m}^{-3} \mathrm{KCl}\right)$ 内部照合電極 $\left.{ }^{4}\right)$ に一部改良を加 えたものを用いた。

\section{3 分極曲線測定}

試作した YSZ 照合電極の応用として，これを照合電 極に用いた分極曲線測定を行った。

試料としては，SUS304 ステンレス鋼（Cr：18.15, $\mathrm{Ni}: 8.52, \mathrm{C}: 0.06, \mathrm{Mn}: 1.21, \mathrm{Si}: 0.76, \mathrm{P}$ : $0.026, \mathrm{~S}: 0.006, \mathrm{Mo}: 0.14, \mathrm{Cu}: 0.13$ mass \%) の 直径 $20 \mathrm{~mm}$, 厚さ $2 \mathrm{~mm}$ の円板状試験片を用いた。試 験片は $1323 \mathrm{~K}\left(1050^{\circ} \mathrm{C}\right)$ で $1.8 \mathrm{ks}(30 \mathrm{~min})$ 真空焼鈍 した後, 水焼き入れを行った。試験片表面はすべて耐水 $\mathrm{SiC}$ 紙で 1500 番まで湿式研磨した後, ダイヤモンド ペーストで $1 \mu \mathrm{m}$ まで鏡面研磨し，アセトン中で超音波 洗浄した。

試験溶液には $298 \mathrm{~K}$ で $\mathrm{pH} 5.8$ の $0.5 \mathrm{kmol} ・ \mathrm{~m}^{-3}$ $\mathrm{Na}_{2} \mathrm{SO}_{4}$ 水溶液を用いた。試験溶液はリザーバ中で精 製 $\mathrm{N}_{2}$ ガスを $43.2 \mathrm{ks}$ （12 h）以上通すことによって脱 気し， $5 \times 10^{-4} \mathrm{~m}^{3}$ を精製 $\mathrm{N}_{2}$ 雾囲気に保ったオートク レーブ中に導入した。オートクレーブに試験溶液を導入 した後, 精製 $\mathrm{N}_{2}$ ガスにより $1 \mathrm{MPa}$ まで加圧した。

高温高圧水中でのアノード分極曲線測定には, 起電力 測定で使用したものと同じオートクレーブを用いた。試 験溶液が目標温度に到達した後 $3.6 \mathrm{ks}(1 \mathrm{~h})$ 経過してか ら試料極を $50 \mathrm{~A} ・ \mathrm{~m}^{-2}$ のカソード電流密度で $0.3 \mathrm{ks}$ （5

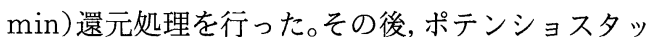
卜を用いた動電位法により, 電位送り速度 $3.8 \times$ $10^{-4} \mathrm{~V} \cdot \mathrm{s}^{-1}$ で試料極の分極曲線を測定した。

\section{4. 実験結果および考察}

\section{1 熱力学的動作試験}

Fig. 3 に, 試作した YSZ 照合電極の $523 \mathrm{~K}$ の 0. $150 \mathrm{kmol} \cdot \mathrm{m}^{-3} \mathrm{NaH}_{2} \mathrm{PO}_{4}$ 中における電位 $E$ の時 間変化を示す。温度が目標の $523 \mathrm{~K}$ に到達し, 一 定になると電位は安定する。423, 473 および $523 \mathrm{~K}$

において安定した電位 $E$ と試験溶液の $\mathrm{pH}$ 値の関 係を Fig. 4 に示す。 $473 \mathrm{~K}$ および $523 \mathrm{~K}$ では電位 $E$ は 溶液の $\mathrm{pH}$ 值に依存せず一定で，この電極が照合電極と して使用できることを示している。 $423 \mathrm{~K}$ においては デー夕のばらつきが大きいが，これは YSZ 素子の感応 下限温度にあることによると思われる。各温度における

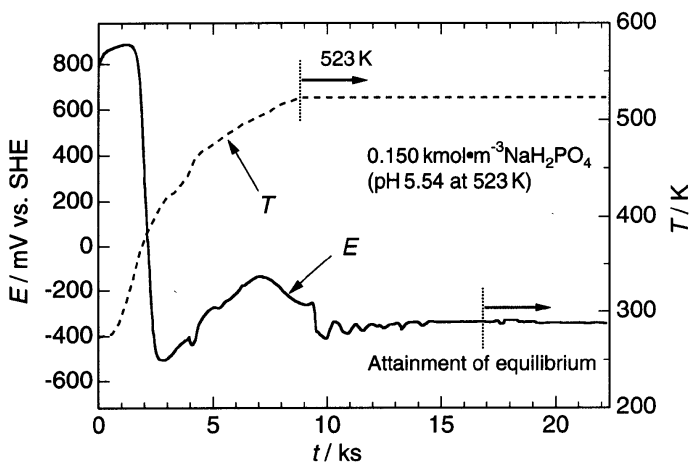

Fig.3 Potential of YSZ reference electrode in phosphate solution (solidline) and temperature of autoclave (broken line) as a function of time.

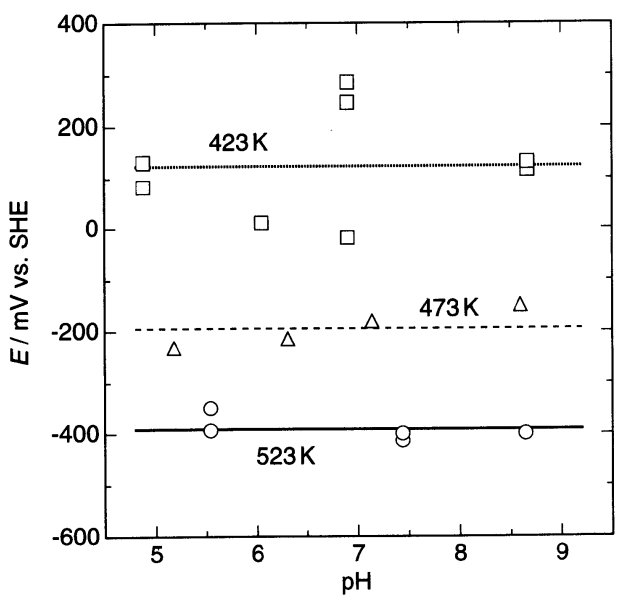

Fig.4 Potential of YSZ reference electrode as a function of solution $\mathrm{pH}$. 


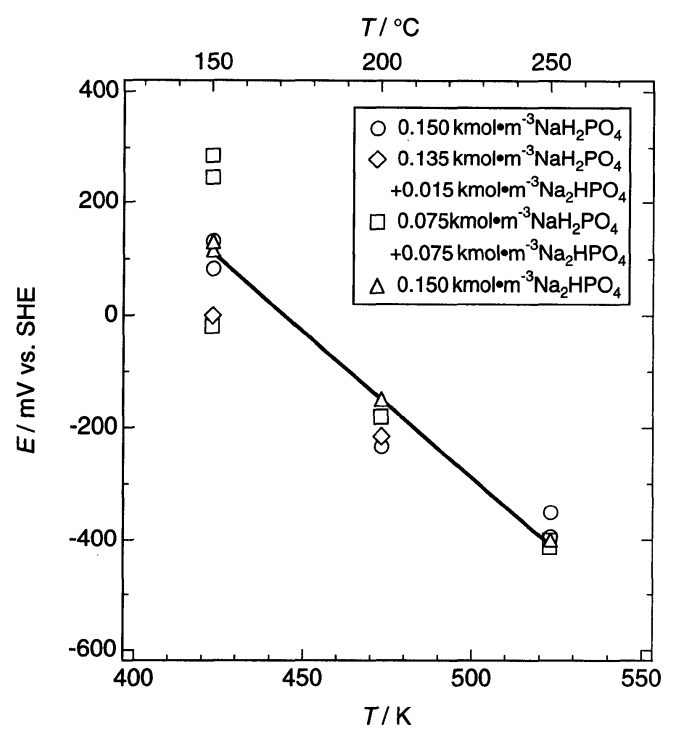

Fig.5 Potential of YSZ reference electrode as a function of temperature.

測定で安定した電位 $E$ と温度 $T$ との関係を Fig. 5 に示 す。Fig. 5 より安定した電位は, $473 \mathrm{~K}$ および $523 \mathrm{~K}$ では pH 5.54 から 8.65 の間では溶液の $\mathrm{pH}$ によらずほ とんど同じ值となっていること, および電位 $E$ と温度 $T$ との間に直線関係が成立することが分かる。Fig. 5 の 電位 $E$ 之絶対温度 $T$ の関係は, 式(6)で表すことができ る。

$$
E=2395-5.37 T / \mathrm{mV} \text { vs. SHE }
$$

一方, $\mathrm{Ni}$ と $\mathrm{NiO}$ との平衡酸素分圧のデー夕 ${ }^{17), 18)}$ に 基づいて計算によって求められた理論式を式(7)に示す。

$$
E_{\text {theor }}=459.8-2.26 T / \mathrm{mV} \text { vs. SHE }
$$

ここで実験式(6) と理論式(7)の切片および傾きの違い は, ジルコニアとの界面において $\mathrm{Ni}$ と平衡する $\mathrm{NiO}$ が 化学量論組成から偏倚していること, 溶液/YSZ 界面と $\mathrm{YSZ} / \mathrm{Ni} \cdot \mathrm{NiO}$ 界面における酸素イオンの空孔の活量が 異なっていること，などが原因であると考えられる。 $\mathrm{NiO}$ の Ar イオンスパッタリングにおいては, 酸素が 選択的にスパッタリングされやすい。そのため, $\mathrm{Ni}$ ・ $\mathrm{NiO}$ 皮膜中の $\mathrm{NiO}$ は非化学量論組成になっている可能 性がある。また。溶液と接する YSZ 表面では水和や溶 解が起こり, 酸素イオン空孔の濃度が変化する可能性が ある。

電極素子の YSZ は酸素イオン伝導性の固体電解質で あり, 低温においては抵抗が非常に高くなる。例えば $423 \mathrm{~K}$ では YSZ(電極面積 $4.4 \times 10^{-5} \mathrm{~m}^{2}$, 厚さ $3 \mathrm{~mm}$ )

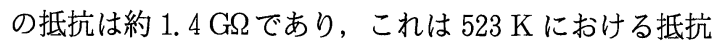
値 6.8 M $\Omega$ の約 200 倍にあたる ${ }^{16)}$ 。したがって低温では 測定中に外部からの電気信号の影響を受けやすく, Fig. 4 および 5 でみられる電位のばらつきはこのよう なことが原因となっているものと思われる。なお，イッ トリア安定化ジルコニアを用いた $\mathrm{pH}$ センサーのこれま での研究では, YSZ 素子の感応下限温度は 443〜 453 K というのが一般的である ${ }^{12) ~ 16) 。 ~}$

\section{2 分極曲線測定試験}

Fig. 6 に試作した YSZ 照合電極を用いて測定した SUS 304 ステンレス鋼の $473 \mathrm{~K}$ および $523 \mathrm{~K}$ における $0.5 \mathrm{kmol} \cdot \mathrm{m}^{-3} \mathrm{Na}_{2} \mathrm{SO}_{4}$ 中でのアノード分極曲線を示し た。Fig. 6 には, $\mathrm{Ag} / \mathrm{AgCl}$ 内部照合電極を用いて測定 した結果 ${ }^{4)}$ も示している。 $\mathrm{Ag} / \mathrm{AgCl}$ 電極による測定で

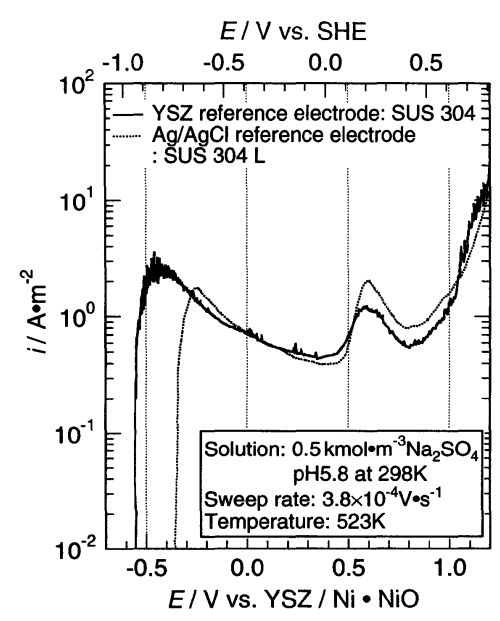

(b) $523 \mathrm{~K}$

(a) $473 \mathrm{~K}$

Fig.6 Anodic polarization curves of SUS 304 stainless steel measured with YSZ reference electrode and $\mathrm{Ag} / \mathrm{AgCl}$ reference electrode. 


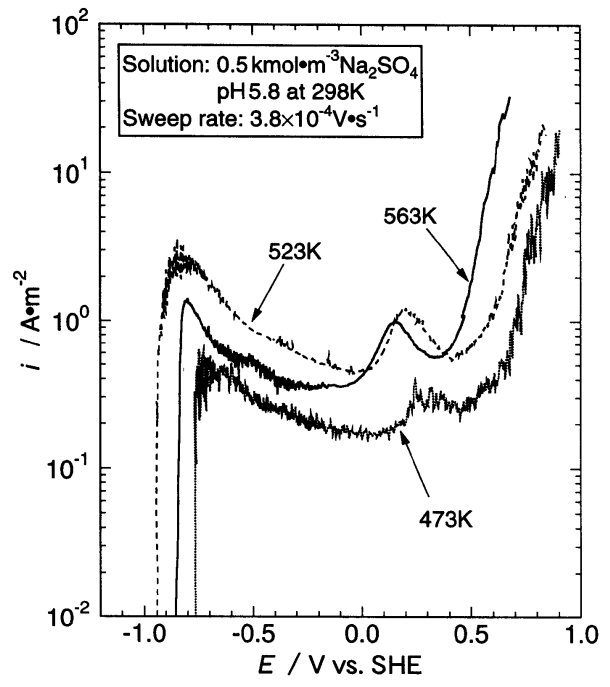

Fig.7 Anodic polarization curves of SUS 304 stainless steel in $0.5 \mathrm{kmol} \cdot \mathrm{m}^{-3} \mathrm{Na}_{2} \mathrm{SO}_{4}$ at temperatures of $473-563 \mathrm{~K}$ measured with YSZ reference electrode.

は, 試料として SUS304 L 鋼が，分極方法として電位 ステップ法（電位間隔： $25 \mathrm{mV}$, 保持時間 : $60 \mathrm{~s}$ ）が用 いられている ${ }^{4)}$ 。なお，YSZ 照合電極を用いて測定し た電位を SHE 基準の電位に換算する際には式(6)の実 験式を用いた。Fig. 6 によれば, $473 \mathrm{~K}$ および $523 \mathrm{~K}$ の いずれの温度においても，分極曲線は腐食電位 $E_{\text {corr }}$ の 值に約 $0.2 \mathrm{~V}$ の違いがあるものの曲線の形状はほぼ一 致している。

Fig. 7 に試作した YSZ 照合電極を用いて測定した SUS 304 ステンレス鋼のアノード分極曲線の 473〜 563 K の範囲の温度による変化を示した。 $423 \mathrm{~K}$ でも同様の 測定を行ったが, 電極素子の YSZ の抵抗が約 $1.4 \mathrm{G} \Omega$ という大きな值のため, 安定な測定結果は得られなかっ た。Fig. 7 において, 過不働態溶解ピーク電位および 酸素発生電位は温度の上昇とともに卑な方へとシフトし ている。また, 活性態ピークの高さおよび不働態維持電 流密度の大きさは $523 \mathrm{~K}$ で最も高くなっている。 $523 \mathrm{~K}$ でアノード溶解速度が大きくなる現象は, 脱気水溶液中 における SUS 304 ステンレス鋼の腐食速度が 523〜 573 K でピークになりそれ以上の温度では減少するという 伊藤らの報告 ${ }^{19)}$ と一致している。

\section{5. 結 論}

（1）基準電極として $\mathrm{Ni} ・ \mathrm{NiO}$ 複合酸化物薄膜をイオ ンビームスパッタ蒸着した安定化ジルコニア（YSZ; $\mathrm{ZrO}_{2}+8$ mol\% $\left.\mathrm{Y}_{2} \mathrm{O}_{3}\right)$ 円板を電極素子として用いた基 準電極一体型固体電解質照合電極を試作した。
（2）試作した照合電極は，423 K，473 K および 523 Kにおいて試験溶液の $\mathrm{pH}$ に依存しない一定の電位を示 した。また, 電位と温度との間には直線関係が認められ た。

（3）試作した照合電極を用いて $473 \mathrm{~K}$ から $563 \mathrm{~K}$ ま での $0.5 \mathrm{kmol} \cdot \mathrm{m}^{-3} \mathrm{Na}_{2} \mathrm{SO}_{4}$ 水溶液中で SUS 304 ステ ンレス鋼のアノード分極曲線を測定したところ， $\mathrm{Ag} /$ $\mathrm{AgCl}\left(0.1 \mathrm{kmol} \cdot \mathrm{m}^{-3} \mathrm{KCl}\right)$ 内部照合電極による測定 結果とほぼ一致した結果を得た。

（4）電極素子の YSZ は高温ほど良い導電率を示す ため, 試作した YSZ 照合電極は $473 \mathrm{~K}$ 以上の温度で測 定温度の上昇と共に良い応答特性を示した。

(Manuscript received March 4,1998; in final form April 17, 1998)

\section{引用文献}

1) M. E. Indig and J. L. Nelson: Corrosion, 47, 202 (1991).

2 ）杉本克久: 防食技術，29，521（1980）.

3) 日本国特許, 特公昭 55-52939.

4 ）杉本克久，相馬才晃：防食技術，31，574 (1982).

5 ) D. D. Macdonald, A.C. Scott and P. Wentrek: J. Electrochem. Soc., 126, 908 (1979).

6 ) D. D. Macdonald, A.C. Scott and P.Wentrek: J. Electrochem. Soc., 126, 1618 (1979).

7 ）滳 孝二：防食技術, 34, 125 (1985).

8 ) M. J. Danielson: Corrosion, 51, 450 (1995).

9 ) D. F. Taylor: Corrosion, 47, 115 (1991).

10) L. W. Niedrach: J. Electrochem. Soc., 127, 2122 (1980).

11) L. W. Niedrach: J. Electrochem. Soc., 129, 1445 (1982).

12) K. Tachibana, A. Hattori, M. Hata and M. Yokoi: Proceedings of JAIF International Conference of Water Chemistry, Japan Atomic Industrial Forum, p.343 (1991).

13）滳 孝二, 服部昭宏, 横井正顕, 小太刀徹, 浅岡 典男: 材料と環境, 40, 308 (1991).

14）滳 孝二：日本原子力学会誌，34，9（1992）.

15) D. D. Macdonald, S. Hettiarachchi, H. Song, K. Makela, R. Euerson and M. Haim: J. Sol. Chem., 21, 849 (1992).

16）河原 亮，相馬才晃，原 信義，杉本克久：「腐 食防食' 95 講演集」, p. 345 , 腐食防食協会 (1995).

17) O. Knacke, O. Kubaschevski and K. Hesselmann: "Thermochemical Properties Inorganic Substance”, Springer-Verlag, p. 1438 (1991).

18) M. W. Chase, Jr., J. L. Curnatt, J. R. Downey, Jr., R. A. McDonald, A. N. Syverud, and E. A. Valenzuela: J. Phys. Chem. Ref. Data, 11, 695 (1982).

19）伊藤伍郎 : 鉄と鋼, 63，345（1971）. 